Eastern Illinois University

The Keep

Faculty Research and Creative Activity

Communication Studies

January 2006

\title{
Memory, Mythmaking, and Museums: Constructive Authenticity and the Primitive Blues Subject
}

\author{
Stephen A. King \\ Eastern Illinois University, saking@eiu.edu
}

Follow this and additional works at: http://thekeep.eiu.edu/commstudies_fac

Part of the Communication Commons, and the Music Commons

\section{Recommended Citation}

King, Stephen A., "Memory, Mythmaking, and Museums: Constructive Authenticity and the Primitive Blues Subject" (2006). Faculty Research and Creative Activity. 13.

http://thekeep.eiu.edu/commstudies_fac/13

This Article is brought to you for free and open access by the Communication Studies at The Keep. It has been accepted for inclusion in Faculty

Research and Creative Activity by an authorized administrator of The Keep. For more information, please contact tabruns@eiu.edu. 


\title{
Memory, Mythmaking, and Museums: Constructive Authenticity and the Primitive Blues Subject
}

Stephen A. King

\begin{abstract}
This essay explores how museums, public memory, and authenticity intersect to privilege an understanding of the past. Reflecting White control over the promotion of blues music, the curators at the Delta Blues Museum, located in Clarksdale, Mississippi, employ two rhetorical strategies to satisfy the expectations of (White) tourists who share culturally specific memories of the blues. First, the museum's rhetorical depiction of blues artists reflects White fascination with the mythic image of the primitive blues subject. Second, the exhibit recreates an early 20th century Delta society to complement tourism goals to market the Mississippi Delta as America's last remaining "pure" blues culture. In the conclusion, implications for rhetorical scholars interested in studying the symbolic dimensions of authenticity are discussed.
\end{abstract}

Since the early 1990s, rhetorical critics (Atwater \& Herndon, 2003; Dickerson, Ott, \& Aoki, 2006; Hasian, 2004; Katriel, 1994) have published a variety of insightful and thoughtful scholarly works on the complex, yet fascinating, relationship between museums and public memory. Yet, much of this research either minimizes the role of authenticity in the construction of institutionalized, authority-driven narratives or fails to mention it altogether. As cultural authorities rhetorically craft and package the past, efforts to construct an authentic heritage site often serve to solidify and privilege cultural memories. Moreover, appeals to authenticity often mirror a larger cultural struggle between powerful institutionalized voices and marginalized communities over the issues of representation and identity. Perhaps one of the most vivid examples of this rhetorical engagement is the recent resurgence of White interest in promoting and marketing an African American musical form, the blues, to a new generation of consumers.

Since the unanticipated commercial success of Delta blues artist Robert Johnson's CD set, the Complete Recordings, in 1990, the blues has experienced another in a series of cultural revivals, generating a multimillion dollar commercial industry as megaconglomerates such as the Miller Brewing Company and Texaco seek out blues artists to sell their products (Gordon, 2002, p. xvi). Meanwhile, this most recent blues revival has also stoked the vivid imaginations of tourists seeking to consume alternative forms of popular culture, a cultural event that parallels an increasing fascination and appetite for American "roots" music. According to Grazian (2003), the blues, in particular, "symbolizes authenticity in a cultural universe populated by virtual realities, artificial intelligences, and a dizzying sense of placelessness" (p. 7). 
In this search for authenticity, many blues tourists find themselves in the Mississippi Delta, often touted as the "birthplace of the blues."

Once ridiculed and condemned for its state-sponsored oppression of African Americans, the state of Mississippi is now capitalizing on the increasing popularity of the blues and the potential financial windfall generated from blues tourists who descend upon the region every year. In the summer of 2004, for example, Mississippi's governor, Haley Barbour, approved the state's first blues commission with the hope of developing a comprehensive plan to market Mississippi's historic blues sites (Farish, 2004, p. 5A). According to Titon (1998), recent efforts are reflective of the "new blues tourism," an organized attempt to create a "mediated" experience for tourists ironically seeking an "authentic" and "genuine" blues experience (p. 5). The new blues tourism is an example of niche tourism, a relatively new development that capitalizes on the increasing efforts of whole communities to accentuate their cultural heritage, "partly in bids to increase their tourism potential" (Connell \& Gibson, 2004, p. 1).

Although the blues is rooted in the experience of Black America, the "guardianship of the blues has passed from the black community to white bohemia" (Davis, 1995, p. 237). Although it would be misleading to suggest that African American audiences have "abandoned" the blues, particularly in the South, a number of observers (Chappell, 1997; Filene, 2000; Kinnon, 1997) have concluded that African Americans - as early as the 1950s-began to find alternative, newer Black music forms, such as R \& B, more appealing because the blues became associated with slavery and sharecropping, poverty and primitiveness, qualities emphasized in the current mass marketing of blues music. Meanwhile, during the 1960s, many middleclass liberal Whites-who rejected traditional cultural and social values-assuaged their alienation with a search for "wholeness, or authenticity, which became associated with 'alternative' cultural practices like blues and jazz" (Schroeder, 2004, p. 99).

Since that time, White promoters and organizers have been largely in control of the preservation and marketing of the blues to a growing number of blues tourists who, according to a number of observers, are themselves middle-to-upper class Whites (Daley, 2003; Davis, 1995; Wald, 2004). In Mississippi, the increasing interest in marketing and promoting the blues reflects this national trend of Whites' "packaging and marketing of what used to be a self-sustaining form of popular culture, created in the back-country lanes and city streets of poor black neighborhoods" (Oakley, 1997, p. 236). For example, the majority of Mississippi blues festival organizations, blues societies, and other blues-related groups are primarily comprised of White members.

In this essay, I demonstrate how the rhetorical dimensions of authenticity and memory play a significant role in the construction and dissemination of privileged cultural narratives to audiences. To this end, this essay will examine and critique the rhetorical practices of the Delta Blues Museum, one of the state's most cherished 
symbols of its "new blues tourism" and the oldest blues museum in Mississippi. At first glance, the Delta Blues Museum's permanent exhibit 1 serves as a powerful reminder of the important role African Americans played in the creation and development of one of America's most popular musical idioms. Yet the Delta Blues Museum also signifies how White promoters and organizers are largely in control of rhetorically creating and disseminating cultural narratives of Mississippi's blues culture to the immediate region and outside world. Since the Delta Blues Museum opened its doors in 1979, all the directors and curators have been White. A curator's world view and cultural assumptions play an important role in the selection and presentation of material artifacts (e.g., guitars) and images (e.g., blues musicians) in an exhibit. In the case of the Delta Blues Museum, selection and presentation decisions inevitably impact "memory-building practices" and how particular memories are packaged for tourists (Katriel, 1993, p. 69).

Employing the term "constructive authenticity," borrowed from tourism studies, I argue that the museum's curators and staff members have employed two rhetorical strategies in order to satisfy the expectations of (White) tourists who typically share culturally specific memories of the blues. 2 First, the museum's depiction of blues artists reflects a blues myth grounded in rhetorical narratives and visual tropes of poverty and primitiveness. Second, by packaging the music and its culture as a static historical object belonging to some bygone era, a time rooted in purity, simplicity, and primitiveness, the museum rhetorically crafts a second blues myth: The Mississippi Delta is the last vestige of an "unpolluted" and "pure" blues culture. The museum's exhibit hall recreates an "authentic" early twentieth-century Delta culture that seemingly satisfies tourists in search of a "pure" blues culture. As Katriel (1994) observed, heritage museums, in particular, are "cultural enclaves whose aura of timeless stability stands in sharp contrast to a world marked by an ethos of change" (p. 1). These rhetorical narratives not only serve to entice tourists to visit the region, and thus fulfill the state's economic aspirations, but perpetuate White control over an African American art form.

In the end, this essay is not concerned with discovering a truly authentic alternative to the current, and some would argue patronizing, White interpretation of blues music. As I argue later in this essay, all authenticity, in one form or another, is a constructed, rhetorical phenomenon - that is to say, from a constructivist perspective, absolute, genuine, "true" authenticity does not exist. As Wang (1999) put it, "There is no absolute and static original or origin on which the absolute authenticity of originals relies" (p. 355). My concern is examining the rhetorical power of cultural authorities in constructing a privileged narrative for museum audiences and exploring how this packaging of history affects public memory and identity. Rhetorical scholars need to recognize the important role authenticity often plays in the construction of memory sites, such as heritage museums, and efforts to explore and analyze the rhetorical dynamics of constructive authenticity are encouraged.

\section{The Delta Blues Museum}


It came as no surprise that Clarksdale, Mississippi became the site of the first blues museum in the state. A number of famous blues musicians, including Muddy Waters, W. C. Handy, John Lee Hooker, Eddie James "Son" House, and Robert Johnson, either grew up in Clarksdale or spent a considerable amount of time honing their craft in clubs and juke joints in the area. Clarksdale is located in Mississippi's Delta region, a multi-county area located in the northwest part of the state. Inspired by these blues masters, local Clarksdale musicians Ike Turner and Sam Cooke went on to establish successful musical careers. According to John Ruskey, former curator of the Delta Blues Museum, "More musicians have come out of Clarksdale than any other one place in the Delta" (quoted in Gillis, 1999, p. 9).

The Delta Blues Museum was established by Clarksdale's local Carnegie Public Library board of trustees in 1979 (Bessman, 1993). The original impetus for creating a blues museum seemed to emerge from the aspirations and interests of local and recently emigrated White entrepreneurs. Sid Graves, the museum's first director-and many would argue the museum's founder and architect—-wanted the museum to promote a new cultural awareness of the significance and meaning of the blues (J. Ruskey, personal communication, April 20, 2001). After Graves retired in 1995, the museum underwent a brief period of instability, as a number of directors were hired and were subsequently fired or left the position. Since the summer of 2003, however, Shelley Ritter has served as the museum's Director and principle curator.

Despite its somewhat isolated rural setting, the museum attracts thousands of visitors every year. According to Ritter (personal communication, September 7, 2004), an estimated 23,000 tourists visited the museum in 2003. Traditionally, most visitors to the museum have been White. Moreover, according to Ritter, most visitors are not from the local community. For example, in October 2002, tourists from 11 countries and 16 states visited the museum (Hood-Adams, 2003, p. 2A). According to Ritter, the few African Americans who enter the museum are either involved in the academic study of the blues or are individuals who are visiting family in the area. For tourists, museums such as the Delta Blues Museum are increasingly becoming important tourist sites because "tourism needs destinations, and museums are premier attractions" (Kirshenblatt-Gimblett, 1998, p. 132).

\section{Museums, Public Memory, and Constructive Authenticity}

Until recently, museums were generally conceived of as "temples," untainted repositories of "truth" guided by a mission to communicate objective and value-free information from an "authoritative source to an uninformed receiver" (HooperGreenhill, 2000, p. 15; McC. Adams, 1999, p. 968). This "transmission model" has been criticized as a "modernist myth" and challenged by scholars (Armada, 1998; Atwater \& Herndon, 2003; Ferguson, 1996; Hasian, 2004; Kavanagh, 1996; Kirshenblatt-Gimblett, 1998; Lavine \& Karp, 1991; McC. Adams, 1999) who argue that museums serve as "powerful rhetorical sites in which the past is selectively 
presented" (Armada, 1998, p. 236). In particular, museums embody societal values because they "operate to discriminate, to emphasise and downplay, to make visible and to put away" (Hooper-Greenhill, 2000, p. 19). Furthermore, a museum's exhibit inevitably reflects the organization's financial resources, accessibility of artifacts, space availability, the personal tastes of its curator(s), and other seemingly invisible, yet highly important factors, including satisfying the museum's target market/visitors.

Curators arguably play the most important role in rhetorically shaping and constructing an exhibit, ultimately serving as a mediator between the past and public observation. Curators base their decisions on a variety of factors from item availability to personal taste. In this way, all museum exhibitions ultimately reflect the "cultural assumptions and the resources of the people who make it" (Lavine \& Karp, 1991, p. 1). Kavanagh (1996) confirmed the curator's important role in reconstructing and reconstituting the past: "Picking and choosing, comparing and contrasting, judging and concluding are acts which constitute curatorial practice. The self, as much as, the "professional' is brought to this and cannot be set aside" ( $p$. 3). Thus, museums are ultimately "political" (Brown \& Davis-Brown, 1998, p. 22) because curators make decisions that are essentially "value-laden, explicitly or implicitly" (Atwater \& Herndon, 2003, p. 19).

Nevertheless, curators cannot completely control how visitors will ultimately come to understand, to give meaning to, or to interpret the artifacts on display. As a museum visitor observes an artifact, according to Kavanagh (1996), "personal memories may be stirred by the images, objects or words made visible and may dominate over any 'formal' history offered" (p. 2). Thus, each visitor-based on his or her own past experiences and priorities-will "select or reject, engage and disconnect from the histories on offer" (p. 3). Museum visitors, thus, play an important role in reinterpreting the meanings of artifacts.

As a rhetorical construction, public or collective memory serves as the intersecting point between institutional forces (e.g., curators) and the public. Public memory is "a body of beliefs and ideas about the past that help a public or society understand both its past, present, and by implication, its future" (Bodnar, 1992, p. 15). As ParryGiles and Parry-Giles (2000) noted, public memory is altogether different than individualized private memories: "Unlike individual memory, which is often only present in thought or confined to documents reserved for private consumption, collective memory is public; it is the publicity of collective memory that establishes its political/rhetorical power" (p. 418). In his review of the scholarship on public memory, Browne (1995) wondered whether a singular and unified public memory can ever exist: "Can we now, if ever we could, even speak of a public memory, for can anything so contingent and contested ever be theorized in the singular?" (p. 237). Articulated in rhetorical practice and embodied in material objects (Sefcovic, 2002), public memory is partial, fragmentary, unpredictable, and unstable (Zelizer, 1995). Thus, subsequent efforts (Atwater \& Herndon, 2003; Biesecker, 2002; Vivian, 2002) to understand the nature of public memory have operated with the 
assumption that a singular public memory is, in fact, largely a fiction because, in the words of Filene (2000), not "all the members of a given public could share [an] identical set of memories" (p. 5).

Although a singular public memory does not exist, the struggle over which public memory becomes privileged typically occurs between "vernacular" and "official" communities (Bodnar, 1992, p. 15; Jorgenson-Earp \& Lanzilotti, 1998, p. 151). While vernacular communities are "ordinary people who often oppose the representations of official culture," official communities are cultural authorities who are concerned with maintaining the status quo (Armada, 1998, p. 237). Thus, the struggle over how the past is remembered confirms Zelizer's (1995) assertion that public memory involves more than simply recalling the past; as a frequently contested form of discourse, public memory reflects issues of "power and authority" as competing groups struggle to create and present a particular understanding of the past ( $p$. 214). Often legitimized by power and status, expertise and prestige, official culture has inherent advantages over its vernacular rival. For example, Ferguson (1996) contended that institutionalized forces use "art objects as elements in institutionalized stories that are promoted to an audience" (p. 175). Institutionalized stories have the power, according to Biesecker (2002), to control how people remember the past. Ultimately, then, as the past is remembered, it is intimately "woven into the present and future" (Zelizer, 1995, p. 217).

At the same time, curators and other members of an exhibition team often employ a rhetorical strategy in which the term "authenticity" is used to conjure specific cultural memories. As Crew and Sims (1991) observed, authenticity often legitimizes how the past should be remembered and how objects and people should be "seen":

Authenticity is not about factuality or reality. It is about authority. Objects have no authority; people do. It is people on the exhibition team who must make a judgment about how to tell about the past. Authenticity-authorityenforces the social contract between audience and the museum, a socially agreed-upon reality that exists only as long as confidence in the voice of the exhibition holds. (p. 163)

As Crew and Sims suggested, authenticity is inherently rhetorical in nature. Although scholars have conceptualized three different types of authenticityobjective, experiential, and constructive-only the last type, constructive, conceives of authenticity as a purely rhetorical construction. 3 "Things appear authentic," according to Wang (1999), "not because they are inherently authentic but because they are constructed as such in terms of points of view, beliefs, perspectives, or powers" (p. 351). For example, tourist intermediaries construct unrealistic expectations and easily ready-made stereotypes of the "native" and the host environment. Silver (1993) examined how tour operators market images of indigenous populations in developing countries in order to "cater to certain images within Western consciousness about how the Other is imagined to be" (p. 302). 
Thus, these indigenous populations are typically represented as static, passive, primitive, exotic, and, above all, authentic.

Thus, in response to the contention that authenticity is rooted in "truth" or "objectivity," constructivists argue that all authenticity is, in one sense or another, an invented and manufactured phenomenon. In this way, authenticity is actually a "shared set of beliefs about the nature of things we value in the world," that are typically "reinforced by the conscious efforts of cultural producers and consumers alike" (Grazian, 2003, p. 12). In his study of Chicago blues clubs, Grazian (2003) lamented that his search for authenticity was doomed to fail because "my very definition of authenticity was, like all definitions of authenticity, based on a mix of prevailing myths and prejudices invented in the absence of actual experience" (p. 12). Even alternative and contradictory depictions of authenticity are "idealized representation[s] of reality" and, thus, act as "a set of expectations regarding how such a thing ought to look, sound, and feel" (Grazian, 2003, p. 10). Since museums feature selected fragments from the past, and thus are divested of the complexities of history, even an African American inspired depiction of blues artists would not be "genuinely" or "objectively" authentic, but simply another perspective on the blues. Yet, as we will see, the Delta Blues Museum's decision to highlight predictable and familiar images of poverty and to depict the Delta as a rural, untamed, and noncommercialized "home of the blues" attempts to satisfy the expectations and cultural memories of (White) tourists who are in search of authentic toured blues objects. While these institutionalized efforts will certainly assist the state in its efforts to expand the financial possibilities associated with blues tourism, it also effectively subverts competing, and often contradictory, images of blues artists.

\section{The Rhetorical Construction of Blues Myths}

Reflective of a popular racial mythology that depicts African Americans as emotional and childlike, poor and illiterate, the image of the "authentic" blues artist is rooted in "white fascination with black singers as primitive, primal figures" (Wald, 2004, p. 256). Indeed, the music's cross-cultural appeal is based largely on its constructed primordial blues figure (Titon, 1998). Wald (2004) observed that since the second blues craze swept the United States in the 1920s, Whites have played a role in rhetorically constructing "a rich mythology that often bears little resemblance to the reality of the musicians they admired." Reconstituted as "primitive voices from the dark and demonic Delta," blues music was transformed from a music characterized by its Black population as exemplifying "professionalism and humor" to an art form enveloped in poverty and destitution, the "heart-cry of a suffering people" (p. 3). In addition, recording companies underscored this stereotypical image with album covers that accentuated rural poverty, while journalistic accounts often stressed the music's emotive and cheerless sound. For example, in 1925, a Vanity Fair reporter described the music as a cacophony of "heart-rending groans and sobs, whimpers and sighs..." (Vechten, 1925, p. 57). In turn, blues music was divested of its "complexity" and characterized as a "natural outpouring of a simple people" who produced a "charming" and "heartfelt" music rooted in "emotion rather than the 
product of talent and craft" (Schroeder, 2004, p. 100). Since the folk-blues boom of the late 1950s, young White blues enthusiasts have mimicked the image of the simple primitive by "donning a work shirt or overalls, hunching over their guitars, and mumbling in their best approximation of Mississippi field inflections" (Wald, 2004, p. 8). Yet, many blues performers, including B. B. King, have openly expressed antipathy toward the image of the dispossessed blues musician:

A bluesman is suppose to be some guy slouched on a stool, a cigarette hanging from his lips, his cap falling off his head, his overalls ripped and smelly, a jug of corn liquor by his side. He talks lousy English and can't carry on a conversation without cussin' every other word. Ask him about his love life and he'll tell you he just beat up his old lady. Give him a dollar and he'll sing something dirty. He's a combination clown and fool. No one respects him or pays him no mind. I resented that. Still do. (King, 1996, pp. 126-127)

Obviously, many blues musicians, particularly artists who grew up in the South during the first half of the twentieth-century, experienced extreme poverty and economic deprivation under the oppressive system of White rule. Black poverty was the result of a myriad of sociopolitical factors, including the destruction and fragmentation of the family structure, political disenfranchisement (lack of voting rights), economic exploitation (sharecropping system), and legalized segregation (Jim Crow laws). Unwilling to acknowledge or to assume responsibility for this social inequality, White society routinely stereotyped African Americans as primitive, lazy, irrational, mentally inferior, and criminally inclined. Although the images of poverty cannot be dissociated from the lives of many early blues artists, it is the rhetorical practice of linking authenticity of the blues to primitiveness that makes the issue of representation and power a particularly salient one for critique.

At first glance, the museum's portrayal of Mississippi's blues artists seems to reject this stereotypical blues persona. For example, in the exhibit's second display area about the history of the blues, the museum showcases a picture of Robert Johnson holding an acoustic guitar and dressed in an elegant pinstripe suit with a handkerchief neatly tucked in his front pocket. This photo, one of only two surviving photos of Johnson, was taken in a professional studio, most likely around the time Johnson's song “Terraplane Blues" became a regional hit in 1936. This free-standing display also contains a collage of pictures, song lyrics, short testimonials from blues musicians and music critics, an old 78 vinyl record, a brief biography, and even a death certificate. Similarly, photos of W. C. Handy, Willie Dixon, B. B. King, and John Lee Hooker feature these musicians dressed in black suits. The museum even sports a life-size mannequin of Muddy Waters clothed in an immaculate white suit and holding an expensive Gibson electric guitar. Beyond these visual representations of success, brief narratives from blues experts acknowledge the contributions of these artists to the development of American popular culture. For example, blues scholar Robert Palmer proclaimed that Charley Patton was "among one of the most important musicians 20th century America ever produced." Through the careful selection of visual images and clipped narratives, these blues artists seemingly 
embody the success of the American dream, not the "ragged, downtrodden minstrels" commonly associated with the romantic description of the poor and dispossessed artist (Wald, 2004, p. 8).

Upon closer examination, these symbols of success are overshadowed by efforts to construct a more "authentic" image of the primordial blues figure. This rhetorical strategy is revealed in numerous ways. First, counterexamples of material success and stature are ever present in the collection. For example, in a memorial to Big Joe Williams, the guitarist is pictured playing his guitar on his porch. Although Williams is the focal point of the picture, the deteriorating porch and exterior wall, along with what appears to be a dirt driveway, symbolize the musician's economic destitution. In another example, the exhibit sports a black and white photo of Lonnie Pitchford staring into a camera while playing a "diddley bow" on a front porch. Before many Delta blues musicians owned a guitar, they often experimented with a diddley bow, an instrument that was created by stretching wire between nails on a wooden board or on the side of a house (Wald, 2004, p. 107). Again, Pitchford's physical surroundings (old wooden porch), along with his "primitive" instrument, signify familiar images of hardship. Finally, visitors will also find the second surviving photograph of Robert Johnson, an image that serves as a striking counterexample to his immaculate studio portrait. Dressed in a workman's white shirt, the unsmiling Johnson is pictured staring into a camera while shaping a complex chord on his guitar. For some visitors, Johnson's stare may suggest anger, resentment, or defiance against the system of White supremacy that did its best to control the lives of African Americans, especially itinerant blues musicians.

Complementing the visual symbols of poverty, there are also a number of tattered instruments on display. Many of the exhibit's acoustic guitars, for example, are disfigured, reflecting the difficult and uncompromising lives of their former masters. The wooden body of Big Joe Williams's guitar, for example, is filled with scratches and nicks, the frets are worn, and the finish on the guitar neck is worn off in several places, revealing a black undercoat finish. Another display features four Stella guitars in various stages of decomposition. In the early twentieth century, the Oscar Schmidt Company manufactured inexpensive 6-string and 12-string guitars, brandnamed "Stella"; the price and availability made these guitars very popular with blues artists such as Leadbelly and Blind Willie McTell (The Stella, 2003, para. 1). Visitors will also find well-worn harmonicas and percussion instruments protected in a glass display case. Although technically "silent," the instruments play a song of the artist's history, craft, struggle, and legacy. For the blues tourist, both visual images and material objects are easily recognizable consumable artifacts.

Moreover, displays featuring individual artists are accompanied by only a few material possessions, an image that may leave some visitors with the impression that blues artists rarely had the financial opportunity to amass material wealth. Of course, all museum displays are inherently incomplete and fragmentary. As Armada (1998) reminded us, museums can "only cue us in to segments of history-they can never represent 'the' past in all of its social, cultural, and political complexity" ( $\mathrm{p}$. 
236). Yet, it is this concept of selectivity that reinforces the image of the itinerant blues musician. Moreover, popular blues travel guides, including Blues Traveling: The Holy Sites of Delta Blues, underscore this theme of displaced poverty; blues singers are described as "rambling sorts who didn't leave behind much in the way of estates, memoirs, letters, or other personal papers or belongings" (Cheseborough, 2001, p. 9). While one cannot deny the fact that many of these musicians were forced to survive in a world of abject poverty, grueling labor-intensive employment, and institutionalized racism, it is also true that some blues musicians, including B. B. King, Buddy Guy, Robert Cray, and other well-known blues entertainers amassed a personal fortune, including houses, cars, and other tangible assets.

Through the use of two display methods, the museum portrays blues musicians as wanderlust paupers. The first type, the glass display case, typically contains the name and a brief biography of an artist, at least one instrument, and a few material objects. For example, the Big Joe Williams case contains a poster-size picture of Williams playing guitar on the edge of an old porch, an acoustic guitar, a vinyl record, and a framed photo of Williams; in the adjoining case, John Lee Hooker is similarly honored - the case includes a large photo of Hooker, an acoustic guitar (signed by Hooker), a record, and four CD covers. Protected by glass and impervious to the touch of visitors, these artifacts personify the lives of musicians whose musical genius was created in a world apparently absent of material possessions and wealth.

The second display type, a single free-standing wooden panel, does not contain the same objects found in display cases. Most of these displays contain only two items: a poster-size picture of a musician and a short biography. The Howlin' Wolf display, for example, contains a black and white poster of Wolf (either in concert or at a recording session). With his eyes closed and his head cocked back, the picture captures Wolf in an exuberant and transcendent pose. Directly above the picture, a short biography describes Wolf's early beginnings and his rise to fame. Framed within the same display type, poster size pictures of other blues legends such as Muddy Waters and Willie Dixon are only accompanied by a brief biographical sketch. This display type suggests that these musicians did not own or leave behind material possessions; others-photographers, biographers, journalists, curatorshelped create artifacts for public consumption, while objects that signify ownership, such as musical instruments, are absent. Thus, the image of the tattered, brokendown musician perfectly compliments displays that depict the penniless blues artist as essentially possession-less, a songster who died in poverty and left the world with only a few material possessions to admire and to worship.

In addition to efforts to construct images of the destitute blues artist, the museum's austere environment is rhetorically constructed to satisfy the expectations of tourists who seek out desirable images of an authentic blues culture. This rhetorical strategy not only provides the necessary context to legitimize and to reinforce the image of the primitive blues singer, it also embodies larger marketing and promotional strategies to perpetuate the romantic vision of the Delta as the 
mythical birthplace of the blues. Although the origins of the blues may never be known, many Delta towns, including Clarksdale, have promoted themselves as the birthplace of the blues. For many blues tourists, the Delta serves as the last bastion of an authentic blues culture untainted by the more commercial and consumerdriven aspects of marketing and tourism commonly associated with bar/restaurant chains such as the House of Blues.

Yet, since the 1920s and 1930s, when the blues was a thriving, innovative musical force in the region, the home of the blues has undergone significant economic and cultural changes. Plagued by depopulation and economic stagnation, this blues haven has witnessed the death of a number of legendary blues musicians and the destruction of numerous blues sites. Warning blues tourists that Mississippi blues is not "the same as it was in 1929-or 1969," Cheseborough (2001) hoped his travel book would help tourists find "what is left in the Mississippi blues world" (pp. 910). More depressing reports claimed that tourists visit the Mississippi Delta to "look at things that aren't there anymore" (Jacobson, 1996, p. 48). Blues musician James "Super Chikan" Johnson (personal communication, December 7, 2004) summed up the dissipating blues culture in Clarksdale: "This being the home of the blues, I mean, there ain't much to see, is there?" As Bodnar (1992) pointed out, while vernacular communities "convey what social reality feels like rather than what it should be like," official culture rearticulates the past "on an abstract basis of timelessness and sacredness" (p. 14).

Blues aficionados who travel to the Delta are very often driven by the desire to experience an unaltered and authentic blues culture. For example, as part of Martin Scorsese's documentary series "The Blues," film director Wim Wenders spent time in the Delta researching the lives of blues musicians Skip James and J. B. Lenoir. According to Wenders, while the blues would become the "best understood universal language," its birthplace essentially remained unchanged. In a highly quixotic narrative of his adventures in Mississippi, Wenders vividly described images that embody the region's supposed timeless essence, a place shrouded in poverty:

I see a lonely shotgun shack here and there, the same old metal chair in faded blue or green forgotten on the porch. The first phrase that comes to mind about houses in Mississippi is corrugated iron. That seems to be the surface of choice-rusty, patched together, trees growing out of the roofs.... A guitar starts, joined by a harmonica.... Even the soft breeze sounds like the blues. (p. 137)

In order to recreate this image of authenticity, the museum emphasizes the rustic and the primitive while eschewing the high-tech world of computer technology. Many contemporary music museums, including the Rock and Roll Hall of Fame (Cleveland) and the Experience Music Project (Seattle) use technological devices (e.g., music instrument booths, computer-generated images) in order to appeal to a generation of younger fans who desire a more engaging, interactive mediated 
environment. In contrast, the Delta Blues Museum has one TV/VCR and a stereo system that pipes music (e.g., Muddy Waters, Robert Johnson) into the exhibition hall. Tony Czech (personal communication, July 1, 2002), the museum's former director, argued that most tourists are not displeased with the museum's low-tech "funky" approach: "It [computerized exhibits] might impress some people, but I think most people just kind of like the sort of low-key ambiance that we've got."

Thus, the museum's "low-tech" approach includes artifacts and materials that existed during a time period when the Delta blues was a popular musical force. The use of wood, brick, and glass, along with items such as cotton bales, farm equipment, and cement tombstones, effectively transports tourists back to the early 1930s, a time when, for example, blues legends Charley Patton and Son House could be spotted playing together in juke joints and house parties in Robinsonville, Mississippi.

In both form and content, wood serves as the museum's primary material element. For example, most of the museum's black and white photos are mounted on large, wooden, sectional dividers used to organize the tourist's first visual narrative-the rural scenery of the Mississippi Delta. And most of these photos feature wooden elements. For example, on one wooden divider, six black and white photos capture familiar Delta surroundings: rivers, swamps, bayous, and flooded fields. All of these photos contain images of various types of trees (e.g., Cypress) indigenous to the area. In another photo, a black dog stands in the middle of a bayou under an early morning, overcast sky. In the background, four large Cypress trees frame both sides of the picture, and another row of trees appears in the far distance. Other photos highlight other wooden structures from barns to rural churches to dilapidated shacks to commissaries. Commissaries served as "early self-contained shopping malls" where members of a community, including tenant farmers and field workers, collected their paychecks and purchased groceries, clothing, and other supplies (Minor, 2002, p. 3G). In all, the sectional dividers and the photos share the same element from nature: wood.

Tourists often are drawn to the Muddy Waters cabin, the largest wooden structure in the museum and a quick, but quiet, reminder of the blues singer's humble beginnings. 4 Before Waters left for Chicago in 1943, he lived in a small cabin on the Stovall Plantation, located on the outskirts of Clarksdale, Mississippi. The one-room cabin is located at the back of the exhibition hall. There is no roof on the cabin; each wall is made of approximately six boards and visitors can peer into the cabin through openings between the boards. The cabin's front exterior wall contains lyrics from familiar songs such as "Mojo Hand," as well as an extended quotation from Waters on the meaning of the blues. The cabin's interior walls contain fragments of Waters's legendary life: a brief history of the cabin, show posters, black and white photos of a young Waters, a Highway 61 sign, vinyl records, and other colorful artifacts. 
As Muddy Waters's biographer, Robert Gordon (2002), observed, the decision to turn the cabin into a visual spectacle speaks to the association of the blues with impoverishment (p. xvi). An obvious example of the commodification of the blues, the cabin's primitiveness represents a powerful myth developed to satisfy White imagination:

It is easy to put Muddy Waters in that cabin, easy to relocate him and his rural beginnings around the world, a neat stitch in the American quiltpicturesque and just the right colors. But easy doesn't make it so. The purity and the simplicity of the blues - its primitiveness - is myth. The blues, like an emotion, is complex. (Gordon, 2002, p. xviii)

Interestingly, while Waters's cabin is safe, protected within the confines of a museum exhibit, his house in Chicago-the same house where the singer wrote many of his greatest songs - stands vacant today, a boarded-up relic forgotten by blues curators and blues fans alike (Gordon, 2002). Apparently, the house did not meet the standards of authenticity; it did not signify primitiveness, an important criteria for preservation. Ironically, at the same time, the cabin's constructed primitiveness - along with the anticipation and excitement of gazing at (even touching) what many consider the Holy Grail of blues tourism-may blind some blues tourists from contemplating the relationship between sharecropper shacks and the practice of sharecropping, a highly inequitable labor-working relationship between White land owners and Black field hands. Thus, the cabin is often remembered not for its exploitative qualities but celebrated for its "purity," a physical reminder of a blues culture that largely exists in the imagination of tourists. Moreover, the cabin's "woodiness," a material quality mirrored throughout the exhibit, reinforces familiar themes of primitiveness and poverty, a key ingredient in the rhetorical construction of an authentic blues site.

To complement these various images, the museum's curators have also included various examples of farm equipment once used to cultivate cotton and other agricultural products. Before the tractor and cotton picker, along with the invention of powerful herbicides and pesticides, effectively replaced and displaced a large majority of Black workers during the late 1940s, farm workers relied almost exclusively on a mule and rudimentary farm equipment to plant the next season's crop. The exhibit contains a rusty planter, a plow, and other farm implements. The end product, a bale of cotton, sits quietly at the back of the exhibit. Interspersed throughout are black and white photos of Black field hands utilizing this equipment during planting season or picking cotton under a burning hot sun. It is important to point out most blues musicians from the South, particularly Mississippi, lived on plantations and worked long hours in the fields, some even before they were old enough to attend elementary school. Highlighting the symbiotic relationship between the blues and hard manual labor, such inclusion of antique farm equipment and photos of Black laborers toiling in cotton fields underscores the grueling working conditions that gave rise to what would later become the constructed image of blues authenticity: the downtrodden, primitive blues artist singing of 
struggle and survival in an unchanging world, waiting to be discovered, admired, and eventually consumed.

\section{Conclusion}

While not denying the import of vernacular culture in contesting ideologically driven narratives, this essay reveals the role of official culture-particularly the politicized nature of curatorial work-in shaping a particular understanding of the past, a strategic move that "reduce[s] the power of competing interests that threaten the attainment of their goals" (Bodnar, 1992, p. 13). This essay illuminates the political and cultural power of heritage museums in influencing how visitors remember the past. In particular, the Delta Blues Museum's permanent exhibit focuses on promoting "authentic" images of primitiveness and impoverishmenticonic symbols that reflect larger, more encompassing, blues mythic narrativesthat arguably satisfy (White) tourists who share culturally specific memories of the blues. At the same time, these mythic narratives serve to racially reinscribe predictable and stereotypical images of the downtrodden, dispossessed blues subject.

The implications of this study suggest that rhetorical scholars should not only explore the rhetorical significance of authenticity in the study of museums and public memory but provide clarity to how the concept is being utilized for analysis. For example, in an intriguing and fascinating examination of the Buffalo Bill Museum (BBM), Dickerson, Ott, and Aoki (2005) include the term "authenticity" in their analysis of both specific artifacts (e.g., a stagecoach) and the BBM. Although it is obvious that the authors are conceptualizing "authenticity" from a rhetorical/constructivist perspective, there is also a sense that authenticity is being framed from the position of an objectivist (BBM artifacts are genuine or "real"). It is imperative that rhetorical scholars specify the type of authenticity used for analysis, particularly in the light that the term is "a polyvalent concept, presenting different meanings to different people" (Frenkel \& Walton, 2000, p. 568).

Moreover, while scholars (Bruner, 2001; Grazian, 2003; Wang, 1999; Young, 1999) in a wide variety of disciplines from anthropology to geography to tourism studies have examined the constructive nature of authenticity, rhetorical critics who have studied authenticity have been inadvertently excluded from this scholarly conversation. As a result, the extant literature on constructive authenticity fails to acknowledge that authenticity is, indeed, a rhetorical practice. Beyond providing an alternative, and more specialized, approach to studying authenticity, rhetorical critics can significantly add to our understanding of the symbolic dimensions of authenticity, providing the wider scholarly community the theoretical and methodological tools to examine and to critique, for example, the rhetorical strategies used by cultural authorities to craft compelling images of authenticity to consumers. At present, however, this essay serves as an initial starting point for pursuing such an inquiry into authenticity. 
The author would like to thank P. Renee Foster, Daniel F. Schowalter, Joy L. Hart, John C. Meyer, and four anonymous reviewers for their insightful and helpful suggestions. Earlier portions of this essay were presented at the 2003 National Communication Association convention in Miami Beach and the 2004 National Communication Association in Chicago.

\section{Notes}

1. The Delta Blues Museum's permanent exhibit is occasionally disassembled in order to make room for the installation of temporary traveling blues exhibits.

2. Since 1998, I have visited the Delta Blues Museum on several occasions. However, this analysis of the museum's exhibit hall was conducted on two occasions: July 1 , 2002 and December 9, 2002. I placed a parenthesis around the word "White" in order to indicate that while Whites are largely attracted to the blues because of its constructed primitiveness, tourists from other countries and different ethnic backgrounds (e.g., Russia, Japan) are drawn to the blues for similar reasons.

3. Objective authenticity refers to the "authenticity of originals" or whether objects are "genuine" or "fake" (Wang, 1999, p. 352). Experiential authenticity, on the other hand, focuses on "tourist experiences" or how specific activities can activate the personal feelings of tourists (Wang, 1999, p. 351).

4. In the 1990s, in an attempt to save the deteriorating wood cabin from the natural elements, the Stovall family (with help from the House of Blues) disassembled the cabin and restored the house to a "half-size replica of its four-room, Muddy-era state" (Cheseborough, 2001, p. 86). From 1996 to 2001, the cabin was part of an extended five-year national tour. In 2001, the museum agreed to temporarily display the cabin to the public.

\section{References}

1. Armada , B. J. (1998). Memorial agon: An interpretive tour of the national civil rights museum. Southern Communication Journal , 63, 235-243.

2. Atwater , D. F. \& Herndon, S. L. ( 2003 ). Cultural space and race: The national civil rights museum and museumAfrica. Howard Journal of Communications , 14,15 28 .

3. Bessman , J. ( 1993 , December 4 ). Ever-growing Delta blues museum keeps music's history alive. Billboard , $105,16,48$.

4. Biesecker , B. A. ( 2002 ). Remembering World War II: The rhetoric and politics of national commemoration at the turn of the 21st century . Quarterly Journal of Speech , 88, $393-409$. 
5. Bodnar , J. ( 1992 ). Remaking America: Public memory, commemoration, and patriotism in the twentieth century . Princeton : Princeton University Press .

6. Brown , R. H. \& Davis-Brown , B. ( 1998 ). The making of memory: The politics of archives, libraries and museums in the construction of national consciousness . History of the Human Sciences , 11, $17-32$.

7. Browne, S. H. ( 1995 ). Reading, rhetoric, and the texture of public memory . Quarterly Journal of Speech , 81, 237- 265.

8. Bruner , E. M. ( 2001 ). The Maasai and the lion king: Authenticity, nationalism, and globalization in African tourism. American Ethnologist , 28, 881 - 908 .

9. Chappell , K. ( 1997 , January ). How blacks invented rock and roll . Ebony , 52 , 52 -54 .

10. Cheseborough , S. ( 2001 ). Blues traveling: The holy sites of Delta blues . Jackson : University Press of Mississippi .

11. Connell , J. \& Gibson, C. ( 2004 ). Music and tourism: The blues, the bizarre, and big business. Geodate , $17,1-5$.

12. Crew , S. R. \& Sims , J. E. ( 1991 ). Locating authenticity: Fragments of a dialogue . In I. Karp \& S. D. Lavine (Eds.), Exhibiting cultures: The poetics and politics of museum display (pp. 159 - 175 ). Washington , D.C. : Smithsonian Institution .

13. Daley , M. ( 2003 ). "Why do whites sing black?": The blues, whiteness, and early histories of rock. Popular Music and Society , 26, $161-167$.

14. Davis , F. ( 1995 ). The history of the blues: The roots, the music, the people from Charley Patton to Robert Cray . New York : Hyperion .

15. Dickerson, G. , Ott , B. L. , \& Aoki , E. ( 2005 ). Memory and myth at the Buffalo Bill museum. Western Journal of Communication , 69, 85 - 108 .

16. Dickerson, G. , Ott, B. L. , \& Aoki , E. ( 2006 ). Spaces of remembering and forgetting: The reverent eye/I at the Plains Indian museum. Communication and Critical/Cultural Studies , $3,27-47$.

17. Farish , J. ( 2004 , June 27 ). Mississippi looks for ways to cash in on the growing interest of historic music culture . Daily Journal , 1A , 5A .

18. Ferguson, B. W. ( 1996 ). Exhibition rhetorics: Material speech and utter sense . In R. Greenberg , B. W. Ferguson , \& S. Nairne (Eds.), Thinking about exhibitions (pp. $175-190$ ). London : Routledge . 
19. Filene , B. ( 2000 ). Romancing the folk: Public memory and American roots music . Chapel Hill : University of North Carolina Press .

20. Frenkel , S. \& Walton, J. ( 2000 ). Bavarian Leavenworth and the symbolic economy a theme town. Geographical Review , $90,559-584$.

21. Gillis , A. M. ( 1999 , May/June ). Destination Delta. Humanities , 20 , 9 - 10 .

22. Gordon, R. ( 2002 ). Can't be satisfied: The life and times of Muddy Waters . Boston : Little, Brown, and Co .

23. Grazian, D. ( 2003 ). Blue Chicago: The search for authenticity in urban blues clubs . Chicago : University of Chicago Press .

24. Hasian , M. , Jr. ( 2004 ). Remembering and forgetting the "final solution": A rhetorical pilgrimage through the U.S. holocaust memorial museum . Critical Studies in Media Communication, 21, 64-92.

25. Hood-Adams , R. (2003, August 20). Play for pay? Museum trustee says blues students, instructor should get extra pay for gigs. Clarksdale Press Register , 1A-2A.

26. Hooper-Greenhill , E. ( 2000 ). Changing values in the art museum: Rethinking communication and learning. International Journal of Heritage Studies , 6 , 9 - 31 .

27. Jacobson , M. ( 1996 , September ). Down to the crossroads . Natural History, $105,48-55$.

28. Jorgensen-Earp , C. R. and Lanzilotti , L. A. ( 1998 ). Public memory and private grief: The construction of shrines at the sites of public tragedy . Quarterly Journal of Speech , $84,150-170$.

29. Katriel , T. ( 1993 ). "Our future is where our past is": Studying heritage museums as ideological and performative arenas . Communication Monographs , 60 , $69-75$.

30. Katriel , T. ( 1994 ). Sites of memory: Discourses of the past in Israeli pioneering settlement museums . Quarterly Journal of Speech , 80 , 1- 20 .

31. Kavanagh , G. ( 1996 ). Making histories, making memories . In G. Kavanagh (Ed.), Making histories in museums (pp. 1 -14). London : Leicester University Press .

32. King , B. B. \& Ritz , D. ( 1996 ). Blues all around me: The autobiography of B. B. King . New York : Avon Books.

33. Kinnon , J. B. ( 1997 , September ). Are whites taking or are blacks giving away the blues? Ebony, $52,86-92$. 
34. Kirshenblatt-Gimblett, B. ( 1998 ). Destination culture: Tourism, museums, and heritage . Berkeley : University of California Press .

35. Lavine , S. D. \& Karp , I. ( 1991 ). Introduction: Museums and multiculturalism . In I. Karp \& S. D. Lavine (Eds.), Exhibiting cultures: The poetics and politics of museum display (pp. 1 - 9). Washington D.C. : Smithsonian Institution .

36. McC. Adams , R. ( 1999 ). Forums, not temples . American Behavioral Scientist, $42,968-976$.

37. Minor , B. ( 2002 , January 20 ). Poor sharecropper shacks see new life in Delta tourism trade . Clarion-Ledger , $3 \mathrm{G}$.

38. Oakley , G. ( 1997 ). The devil's music: A history of the blues 0 , 2nd ed. . London : Da Capo Press .

39. Parry-Giles , S. J. \& Parry-Giles , T. ( 2000 ). Collective memory, political nostalgia, and the rhetorical presidency: Bill Clinton's commemoration of the march on Washington, August 28, 1998. Quarterly Journal of Speech , 86 , 417 - 437.

40. Schroeder , P. R. ( 2004 ). Robert Johnson, mythmaking, and contemporary American culture. Urbana : University of Illinois Press .

41. Sefcovic , E. M. I. ( 2002 ). Cultural memory and the cultural legacy of individualism and community in two classic films about labor unions . Critical Studies in Media Communication , 19, 329 - 351 .

42. Silver , I. ( 1993 ). Marketing authenticity in third world countries . Annals of Tourism Research , 20, $302-318$.

43. The Stella 12-string guitar (n.d.). Retrieved June 22 , 2003 , from http://www.toad.net/ harpe/stella_12string.htm .

44. Titon , J. T. ( 1998 ). The new blues tourism . Arkansas Review: A Journal of Delta Studies , 29, $5-10$.

45. Vechten , C. V. ( 1925 , August ). The black blues: Negro songs of disappointment in love . Vanity Fair , $12,57,86,92$.

46. Vivian , B. ( 2002 ). Jefferson's other . Quarterly Journal of Speech , 88 , 284 302.

47. Wald , E. ( 2004 ). Escaping the Delta: Robert Johnson and the invention of the blues . New York : HarperCollins . 
48. Wang , N. ( 1999 ). Rethinking authenticity in tourism experience . Annals of Tourism Research , 26, $349-370$.

49. Wenders , W. ( 2003 , September ). Sighting the blues . Conde Nast Traveler , 38 , $136-137$.

50. Young , M. ( 1999 ). The social construction of tourist places . Australian Geographer, 30 , $373-389$.

51. Zelizer , B. ( 1995 ). Reading the past against the grain: The shape of memory studies . Critical Studies in Mass Communication , 12, $214-239$. 